Tentunya yang dituntut utnuk seorang guruadalah keterampilan dalam membuat sebuah media pembelajaran yang sesuai sehingga tercapai tujuan pembelajaran dan siswanya dapat belajar dengan lebih menyenangkan.

Belajar menyenangkan tentu hal tersebut sangat dibutuhkan oleh anak di usia dini dan salah satu cara yang dilakukan adalah menggunakan media pembelajaran. Atwi Supratman (1997) media merupakan alat yang digunakan untuk menyalurkan pesan atau informasi dari pengirim kepada penerima pesan. Sedangkan dalam aktivitas pembelajaran, media adalah sesuatu yang dapat membawa informasi dan pengetahuan dalam intraksi yang berlangsung antara pendidik dan peserta didik (Fathurrohman \& Sutikno, 2007).

Berdasarkan definisi dari media dari beberapa ahli dapat dikatakan bahwa media merupakan alat bantu bagi guru dalam proses pembelajaran, namun media dapat menjadi penghambat jika penggunaannya tidak sesuai dengan esensi tujuan yang telah dirumuskan. Menurut Falahudin (2014) manfaat media dalam pembelajaran sebagai berikut: a. proses pembelajaran mejadi lebih jelas dan menarik, b. efisien dalam waktu dan tenaga, c. dapat menumbuhkan sikap positif terhadap materi dan proses belajar, d. dapat membantu mengatasi keterbatasan indra manusia.
Media pembelajaran yang baik harus dapat disesuaikan dengan penekatan, metode dan model pembelajaran serta menganalisis kebutuhan siswa. Memilih dan memanfaatkan media pembelajaran memiliki prinsip yaitu prinsip motivasi, perbedaan individu, tujuan pembelajaran (Arsyad, 2014). Penggunaan media pembelajaran yang sesuai dapat membuat proses pembelajaran menjadi lebih variatif, interaktif, menyenangkan.

Menurut Fathurrohman \& Sutikno, (2007), jenis media dibagi ke dalam media auditif, visual, dan media audiovisual. Dalam pengabdian ini media yang digunakan termasuk media visual. Media visual adalah media yang hanya mengandalkan indra penglihatan seperti menampilkan gambar atau simbol yang bergerak, foto, lukisan dan cetakan.

Berdasarkan hasil observasi di Taman Kanak-kanak Darmawanita Desa Lito, penggunaan media oleh guru masih belum maksimal dan lebih banyak memanfaatkan papan tulis dalam proses belajar serta media yang biasa digunakan belum berbasis saintifik.

Lapbook salah satu jenis media visual yang menampilkan gambar dan foto. Lapbook tepat digunakan untuk pembelajaran tematik yang berbasis saintifik. Lapbook pada umumnya terbuat dari salah satu jenis map, yaitu file-folder yang 
kemudian dilipat secara vertikel atau horizontal menjadi dua sehingga menjadikannya seperti berjendela apabila map tersebut dibuka.

Saintifik merupakan pendekatan dalam proses pembelajaran yang mengintegrasikan keterampilan sains yaitu mencari tahu sendiri fakta-fakta dan pengetahuan yang dikaitkan dengan materi pembelajaran (Ine, 2015). dalam penerapan saintifik terdapat aktivitas yang dapat diobservasi seperti mengamati, menanya, mengolah, menalar, menyajikan menyimpulkan dan mencipta. Menurut Musfiqon \& Nurdiansyah (2015) pendekatan saintifik mempunya hasil yang efektif bila dibandingkan dengan penggunaan pembelajaran dengan pendekatan tradisional.

Menurut Daryanto (2014) proses pembelajaran sanitifik memiliki kriteria sebagai berikut: Pertama, materi pembelajaran berbasis pada fakta atau fenomena yang dapat dijelaskan dengan logika atau penalaran tertentu. Kedua, proses pembelajaran harus terhindar dari sifat non ilmiah.

Pembelajaran saintifik bertujuan untuk membiasakan peserta didik berfikir, bersikap, serta berkarya. Proses pembelajaran menjadi lebih penting dan bermakna.

\section{METODE PENELITIAN}

Pengabdian ini dilaksanakan pada guru-guru Taman Kanank-Kanank "Tunas 68

Wiwi Noviati \& Eryuni Ramdhayani: Pelatihan Pembuatan Media Lapbook Berbasis Saintifik untuk Guru Taman Kanak-Kanak (TK) di Desa Lito
Bangsa" Desa Lito berjumlah 4 orang. Teknologi yang digunakan adalah pelatihan pembuatan media lapbook berbasis saintifik.

Metode pengabdian ini berupa pelatihan, ceramah, diskusi serta demonstrasi praktek langsung. Sesuai dengan permasalahan bahwa guru belum manggunakan media lapbook berbasis saintifik. Dalam penerapan saintifik tidak terlepas dari penggunaan media sebagai salah satu sarana dalam melaksanakan tahap saintifiknya.

Kegiatan pelatihan dilaksanakan dengan tujuan untuk memberi bekal pengetahuan kepada guru-guru tentang pembuatan media lapbook berbasis saintifik.

Untuk merancang kegiatan apa yang sesuai dengan kebutuhan, tim telah melakukan 2 kali pertemuan yakni:

1) Dalam pertemuan pertama yaitu Persiapan: Tim mengurus surat izin dan surat tugas untuk melaksanakan pengabdian. Tim melakukan kunjungan ke lokasi meninjau langsung proses pembelajaran serta media yang biasa digunakan dalam proses pembelajaran. Tim menyiapkan semua alat dan bahan yang diperlukan dalam pembuatan media lapbook berbasis saintifik.

2) Dalam pertemuan kedua tim melakukan pelatihan pembuatan lapbook berbasis saintifik. 


\section{ALAT DAN BAHAN}

Alat yang digunakan dalam pembuata lapbook ini terdiri kertas manila, kertas gambar, pensil warna, penggaris, gunting, Koran, majlah, lem. Berikut ini akan diuraikan fungsi masing-masing alat tersebut dalam pembuatan lapbook.

Table 1. Alat dan bahan lapbook

\begin{tabular}{ll}
\hline \multicolumn{1}{c}{ Alat } & Fungsi \\
\hline $\begin{array}{l}\text { Kertas } \\
\text { manila }\end{array}$ & Sebagai alas \\
\hline $\begin{array}{l}\text { Kertas } \\
\text { gambar }\end{array}$ & Mengambar \\
\hline Pensil warna & Untuk menggambar \\
\hline Penggaris & Untuk menggambar \\
\hline Gunting & $\begin{array}{l}\text { Untuk menggunting gambar, } \\
\text { koran dan majalah }\end{array}$ \\
\hline Koran & $\begin{array}{l}\text { Untuk tempat memilih gambar } \\
\text { atau materi }\end{array}$ \\
\hline Majalah & $\begin{array}{l}\text { Untuk tempat memilih gambar } \\
\text { atau materi }\end{array}$ \\
\hline Lem & $\begin{array}{l}\text { Untuk menmpelkan gambir di } \\
\text { kertas manila }\end{array}$ \\
\hline
\end{tabular}

\section{HASIL DAN PEMBAHASAN}

Kegiatan pelatihan ini melibatkan guru-guru TK Darmawanita yang berjumlah 4 orang. Kegiatan palatihan dibuka oleh pengawas. Selanjutnya dilanjutkan dengan kegiatan penyampaian materi tentang media lapbook dan pembelajaran berbasis saintifik dilakukan melalui media power point sehingga bisa menampilkan contoh media lapbook yang sudah pernah dibuat oleh orang lain. Tujuannya sebagai acuan guru yang mengikuti pelatihan agar tidak bingung nantinya dengan media yang akan dibuat.

Kegiatan selanjutnya setelah selesai penyampaian materi, guru-guru yang mengikuti pelatihan mulai bersiap dengan bahan dan alat yang telah disiapkan untuk membuat media lapbook. Pembuatan media lapbook berbasis saintifik dilakukan oleh guru perindividu. Adapun cara pembuatan media lapbook berbasis saintifik sebagai berikut: a. terlebih dahulu guru menentukan tema dari media lapbook yang akan dibuat, karena pembelajaran dilakukan secara tematik, b. guru mulai menggambar materi yang sesuai dengan tematik, selain menggambar guru juga mengambil dari koran dan majalah, c. selanjutnya tahap menempel bahan yang telah digambar dan digunting tersebut di atas kertas manila, d. Setelah selesai masing-masing guru mendemonstrasikan media lapbook di depan sesuai dengan proses pembelajaran di kelas.

Tentunya dalam pembuatan media ini harus muncul ilmiahnya karena berbasis saintifik, sehingga siswa belajar menemukan suatu permasalahan dengan melihat gambar dari media dan menghubungkan dengan pengetahuan dan kehidupan sehari-hari. Melalui pembelajaran berbasis saintifik siswa akan mampu belajar dengan menemukan suatu masalah dan belajar mengatasi masalah tersebut. Proses pembelajaran seperti ini sudah patut dikenalkan pada siswa usia dini selain mengembangkan kemampuan berpikir mereka juga mampu menerapkan dalam kehidupan sehari-hari.

Pada saat proses demonstrasi guru mengarahkan siswa untuk menemukan 
masalah dari media lapbook yang dibuat melalui penjelasan guru. Kemudian mengarahkan siswa untuk mencari jawaban dari permasalahan tersebut dengan mengumpulkan pengetahuan atau ide yang siswa punya dan menyampaikan kepada guru.

Bagi guru-guru yang mengikuti pelatihan ini, kesulitan yang mereka alami pada saat mendemonstrasikan media lapbook yang telah disusun karena menerapkan pembelajaran saintifik, dengan memberikan pemahaman pada anak sehingga mampu memunculkan proses saintifik yang diinginkan. Namun kesulitan tersebut menjadi tantangan bagi guru-guru karena sesuatu hal yang baru memang tidak mudah untuk diterapkan dalam proses pembelajaran.

\section{SIMPULAN DAN SARAN}

\section{Simpulan}

Kegiatan pelatihan pembuatan media lapbook berbasis saintifik menjadi tambahan pengetahuan yang baru bagi guru-guru TK Darmawanita yang dapat dikembangkan dan dimanfaatkan dalam proses pembelajaran. Hal ini terlihat dari antusias guru-guru dalam membuat media dan mendemonstrasikan di depan hasil karya mereka masing-masing.

\section{Saran}

Pengabdian kepada masyarakat yang berjudul pelatihan pembuatan media lapbook berbasis sanitifik. Adapaun saran yang dapat diberikan dari hasil pelatihan yaitu hendaknya kegiatan seperti ini sering dilakukan untuk meningkatkan keterampilan dan kreativitas guru-guru TK dalam membuat media pembelajaran yang digunakan dalam proses pembelajaran, sehingga media yang digunakan dapat bervariasi dan tidak membosankan.

\section{DAFTAR PUSTAKA}

Arsyad, Azhar. 2014. Media Pendidikan. Jakarta: PT. Jakarta Grafindo Persada.

Ine Maria Emanuela, 2015. Penerapan Pendekatan Scientific untuk Meningkatkan Prestasi Belajar Siswa Pada Mata Pelajaran Ekonomi POkok Bahasan Pasar. Prosidding Seminar Nasional. Universitas Negeri Surabaya.

Daryanto. 2014. Pendekatan Saintifik Kurikulum 2013. Yogyakarta: Gava Media.

Musfiqon, Nurdiansyah. 2015. Pendekatan Pembelajaran Saintifik. Sidoarjo: NLC.

Faturrohman Pupuh, Sobry Sutikno. 2007. Strategi Belajar Mengajar. Bandung: PT. Refika Aditama.

Falahudin Iwan. 2014. Pemanfaatan Media dalam Pembelajaran. Jurnal Lingkar Widyaiswara Edisi 1. No.4. Hal. 104117. 


\title{
PELATIHAN PEMBUATAN HERBARIUM SEBAGAI MEDIA PEMBELAJARAN KEANEKARAGAMAN HAYATI PADA KELAS VIII SMP NEGERI 3 MOYO HULU TAHUN 2017
}

\author{
Oleh \\ Indah Dwi Lestari'), Syafruddin²) \\ 1),2) Dosen Program Studi Pendidikan Biologi FKIP Universitas Samawa \\ Indahlestari656@gmail.com
}

\begin{abstract}
ABSTRAK
Tujuan pengabdian masyarakat ini adalah sebagai pengembangan media pembelajaran di SMP dan tambahan informasi serta pengetahuan tentang pembuatan spesimen herbarium. Kegiatan pengabdian ini dilaksanakan selama satu hari dengan melibatkan guru Bidang Studi Biologi dan siswa kelas VIII SMP Negeri 3 Moyo Hulu. Hasil kegiatan pengabdian ini adalah sangat baik, hal tersebut dapat terihat dari antusiasme siswa yang terlibat dalam kegiatan tersebut. Antusiasme tersebut dapat terlihat dari bagaimana mereka bertanya dan menjawab pertanyaan yang diberikan terkait dengan kegiatan tersebut. Selain itu kerjasama dari pihak sekolah baik itu Kepala Sekolah, Wakasek, serta Guru Bidang studi menunjukkan sikap kerjasama yang baik sehingga kegiatan tersebut berjalan dengan baik dan bermanfaat. Setelah melakukan diskusi terkait dengan keberlanjutan kegiatan ini Pihak Sekolah sangat menginginkan adanya kegiatan yang lain yang nantinya dapat meningkatkan motivasi mauapun hasil belajar siswa, khususnya dalam bidang studi Biologi.
\end{abstract}

Kata kunci: Herbarium, Tumbuhan, Media Pembelajaran

\section{PENDAHULUAN}

Pada saat sekarang ini pendidikan bukan hanya terapku hanya pada buku teks saja sebagai pegangan dalam proses pembelajaran, salah satu usaha yang dapat dilakukan oleh guru adalah dengan pengembangan dan inovasi media pembelajaran yang menarik yang nantinya dapat meningkatkan motivasi maupun hasil belajar siswa.

Pembelajaran berbasis lingkungan, termasuk pemanfataan lingkungan seperti objek organisme langsung di lingkungan atau melalui pengawetan dan preparasi objek organisme seperti tumbuhan, cukup mendukung untuk tercapainya kompetensi dan tujuan pembelajaran yang optimal. Sa;ah satu cara untuk mencapai tujuan tersebut adalah dengan pembuatan Herbarium. Herbarium merupakan teknik pengawetan tumbuhan baik itu kering maupun basah. Herbarium sangat erat kaitannya dengan kebun botani maupun pendidikan dalam hal ini media pembelajaran.

$$
\text { Pengetahun tentang teknik }
$$
pengawetan tumbuhan (Herbarium) sangat penting diketahui oleh guru Biologi, dengan media ini guru akan sangat terbantu dalam memberi penjelasan mengenai ciri-ciri tumbuhan secara langsung. Proses pembuatan herbarium kering spesimennya 
dipres dan dikeringkan,serta ditempelkan pada kertas kemudian diberi label berisi keterangan yang penting tentang spesimen tersebut, sedangkan herbarium basah diawetkan dengan menggunakan larutan sepeti FAA atau alkohol.

SMP Negeri 3 Moyo Hulu, merupakan salah satu sekolah yang telah menjalin kerjasama dengan Universitas Samawa khususnya FKIP. Oleh karena itu pemilihan sekolah ini untuk menjadi sasaran kegiatan pengabdian dirasa cocok, selain itu letak sekolah yang disekitarnya masih terdapat hutan potensial untuk memanfaatkan sumber daya yang ada dalam hal ini keanekaragaman hayati sehingga dapat melakukan proses pembelajaran berbasis lingkungan.

\section{KAJIAN PUSTAKA}

\section{Pengertian Herbarium}

Herbarium berasal dari kata " hortus dan botanicus", artinya kebun botani yang di keringkan,biasanya disusun berdasarkan system klasifikasi. Istilah herbarium lebih dikenal untuk pengawetan tumbuhan. Herbarium adalah material tumbuhan yang telah diawetkan (disebut juga spesimen herbarium) (Triharso, 2006) Herbarium juga bisa berarti tempat dimana material-material tumbuhan yang telah diawetkan disimpan.

Herbarium merupakan suatu spesimen dari bahan tumbuhan yang telah dimatikan dan diawetkan melalui metode tertentu. Herbarium biasanya dilengkapi dengan data-data mengenai tumbuhan yang diawetkan, baik data taksonomi, morfologi, ekologi, maupun geografinya. Selain itu dalam herbarium juga memuat waktu dan nama pengkoleksi.

Herbarium juga merupakan salah satu sumber pembelajaran yang penting dalam ilmu biologi tumbuhan. Herbarium merupakan koleksi kering yang dibuat berdasarkan prosedur-prosedur tertentu dan memiliki criteria criteria tersendiri.

Secara umum ada dua jenis herbarium,yaitu herbarium basah dan herbarium kering. Herbarium yang baik slalu di sertai identitas pengumpul ( nama pengumpul atau kolektor dan nomor koleksi).

Koleksi herbarium merupakan kekayaan yang tak ternilai harganya bagi para ahli taksonomi. Seringkali koleksi-koleksi herbarium disimpan dalam gedung-gedung yang megah dilengkapi dengan peralatan kompleks dan dikelola para pakar taksonomi beserta tenaga administrasi dan teknisi. Indonesia memiliki gedung herbarium Bogoriense yang berada di kompleks Cibinong Science Center LIPI. Gedung herbarium ini merupakan herbarium terlengkap dan tertua di Asia Tenggara, serta nomor tiga terbesar di seluruh dunia. 